\title{
ERRATUM
}

\section{Hunter-Gatherers in a Changing World}

\author{
Victoria Reyes-García and Aili Pyhälä \\ (C) Springer International Publishing Switzerland 2017 \\ V. Reyes-García, A. Pyhälä (eds.), Hunter-Gatherers in a Changing World, \\ DOI 10.1007/978-3-319-42271-8
}

DOI 10.1007/978-3-319-42271-8_14

This book was mistakenly published with the word 'NonCommercial' contained in the Open Access copyright text for a Creative Commons Attribution 4.0 International License. The PDF and HTML versions have now been updated with the correct terms for a CC BY 4.0 license, as follows:

\section{Corrected license text on Copyright page:}

Chapter 10 is licensed under the terms of the Creative Commons Attribution 4.0 International License (http://creativecommons.org/licenses/by/4.0/). For further details see license information in the chapter.

Corrected license text at the end of Chapter 10 (before the references section):

This chapter is licensed under the terms of the Creative Commons Attribution 4.0 International License (http://creativecommons.org/licenses/by/4.0/), which permits use, sharing, adaptation, distribution and reproduction in any medium or format, as long as you give appropriate credit to the original author(s) and the source, provide a link to the Creative Commons license and indicate if changes were made.

The images or other third party material in this chapter are included in the chapter's Creative Commons license, unless indicated otherwise in a credit line to the

The updated original online version for this book can be found at DOI 10.1007/978-3-319-42271-8 
material. If material is not included in the chapter's Creative Commons license and your intended use is not permitted by statutory regulation or exceeds the permitted use, you will need to obtain permission directly from the copyright holder.

\section{Corrected license text on back cover:}

Chapter 10 is open access under a CC BY 4.0 license. 